\title{
Events Surrounding the Early Development of Euglena Chloroplasts: Cellular Origins of Chloroplast Enzymes in Euglena*
}

\author{
By JOAN G. BOVARNICK, J. A. SCHIFF, Z. FREEDMAN AND \\ J. M. EGAN, JUN. \\ Department of Biology, Brandeis University, Waltham, Massachusetts 02154, U.S.A.
}

(Received 12 November 1973)

\section{SUMMAR Y}

During chloroplast development, the large increases in ribulose diphosphate carboxylase (RUDPCase) activity and cytochrome $55^{2}$ concentration follow the pattern of chlorophyll synthesis, in that the formation of these two enzymes is inhibited by streptomycin $(\mathrm{Sm})$ and by chloramphenicol $(\mathrm{Cm})$ beyond $\mathrm{I} 2 \mathrm{~h}$ of development. Neither enzyme can be detected in $\mathrm{w}_{3} \mathrm{BUL}$, a mutant of Euglena in which chloroplasts and chloroplast DNA are undetectable. In contrast, the NADP-linked triose phosphate dehydrogenase (NADP-TPDase), another plastidlocalized enzyme, increases in activity without the $\mathrm{I} 2 \mathrm{~h}$ lag normally observed for chlorophyll synthesis; this increase in activity is not inhibited by $\mathrm{Sm}$ and $\mathrm{Cm}$, but is inhibited by cycloheximide, an antibiotic which acts on $87 \mathrm{~S}$ cytoplasmic ribosomes. NADP-TPDase activity is present at the same level in $\mathrm{w}_{3} \mathrm{BUL}$ as in the dark-grown wild-type organisms. These data are interpreted to mean that NADP-TPDase is coded in the nuclear DNA, and is translated on $87 \mathrm{~S}$ cytoplasmic ribosomes. The sensitivity of the increase in cytochrome 552 and RUDPCase activities to Sm and $\mathrm{Cm}$ indicates that they are translated, at least in part, on the $68 \mathrm{~S}$ ribosomes of the chloroplast. Thus, chloroplast differentiation in Euglena is dependent upon information and synthetic machinery from both the plastid and the rest of the cell. Since total cellular protein does not change significantly during chloroplast development in resting cells, we conclude that protein turnover probably occurs.

\section{INTRODUCTION}

The finding that many constituents required for chloroplast development may come from outside the plastid (Schiff, Zeldin \& Rubman, 1967; Schiff, I971; Schiff \& Zeldin, 1968; Smillie, 1968) suggests that certain chloroplast molecules might be supplied through synthetic activities and informational contributions from outside the chloroplast. Certain antibiotics, such as chloramphenicol and streptomycin, selectively inhibit protein synthesis on $68 \mathrm{~S}$ plastid ribosomes, but have little or no effect on cell division or viability in Euglena, implying that they do not inhibit protein synthesis on the $87 \mathrm{~S}$ cytoplasmic ribosomes (Smillie et al. 1967; Provasoli, Hutner \& Schatz, 1948; Avadhani \& Buetow, $1972 b$; Schwartzbach, Freyssinet \& Schiff, 1973; Bovarnick, Chang, Schiff \& Schwartzbach, I974). In addition, mutant strains of Euglena are available in which plastid DNA is undetectable (Edelman, Schiff \& Epstein, I965) providing a means of determining whether chloroplast DNA is involved in coding or controlling the formation of these plastid proteins. From the enzymes which have been localized in the plastids of Euglena (Smillie, Evans \& Lyman, I963; Smillie, I968), we have chosen ribulose diphosphate carboxylase (Fuller \& Gibbs, 1959; Latzko \& Gibbs, 1968) the NADP-linked triose phosphate dehydrogenase

* No. 4 of a series. 
(Heber, Pon \& Heber, 1963; Pupillo, 1972), both enzymes of the carbon dioxide fixation cycle, and cytochrome 552 (Perini, Schiff \& Kamen, I964; Nishimura, I959; Wolken \& Gross, 1963; Katoh \& San Pietro, 1967), a member of the photosynthetic electron transport chain. A preliminary account of this work has been presented (Bovarnick, Freedman \& Schiff, 1970).

\section{METHODS}

Euglena gracilis Klebs var. bacillaris Pringsheim and $\mathrm{w}_{3} \mathrm{BUL}$, an aplastidic mutant derived from this strain in which plastid DNA is undetectable (Edelman et al. 1965) were used in the present study. The methods for cultivation and maintenance of the organisms as well as the techniques for use of streptomycin (Sm) are described in the accompanying paper (Bovarnick et al. 1974). Streptomycin was added to 3-day-old resting cells at a final concentration of $0.05 \%$, immediately before cultures were exposed to light. Chloramphenicol $(\mathrm{Cm})$ was used at a final concentration of $2 \mathrm{mg} / \mathrm{ml}$. For studies of plastid development, sterile resting medium containing $4 \mathrm{mg} \mathrm{Cm} / \mathrm{ml}$ was added to an equal volume of medium containing 3-dayold resting organisms; control cultures were diluted with an equal volume of resting medium lacking $\mathrm{Cm}$. Cultures were placed in the light immediately after $\mathrm{Cm}$ addition. Cycloheximide was used at a final concentration of I $5 \mu \mathrm{g} / \mathrm{ml}$. Chloramphenicol and cycloheximide were sterilized by millipore filtration.

The techniques for determination of chlorophyll, carotenoid and photosynthetic $\mathrm{CO}_{2}$ fixation, as well as the assays of the NADP-linked triose phosphate dehydrogenase (NADPTPDase), ribulose diphosphate carboxylase (RUDPCase) and cytochrome 552 , are described in the accompanying paper (Bovarnick et al. 1974). NAD-linked triose phosphate dehydrogenase was assayed according to the method given for NADP-TPDase, except that NADH was substituted for NADPH. The NAD enzyme retained its full activity for several hours in the ice bath.

For measurements of the protein content of whole organisms the following method was employed. Suspensions were centrifuged for $10 \mathrm{~min}$ at $\mathrm{I} I 00 \mathrm{~g}$, and the pellet extracted with acetone at room temperature. After recentrifugation the pellet was resuspended in $\mathrm{NaOH}$, heated in a water bath for $5 \mathrm{~min}$ at $60^{\circ} \mathrm{C}$, and then left in the refrigerator overnight or kept in the frozen condition for several days. The suspension was then centrifuged and the supernatant fluid used for protein assays which employed standard procedures (Lowry, Rosebrough, Farr \& Randall, I95I) using the alternative of preparing the $\mathrm{Na}_{2} \mathrm{CO}_{3}$ solution in water rather than in $\mathrm{NaOH}$. If insufficient $\mathrm{NaOH}$ was present after adding the protein solution, more was added at this point before proceeding with the usual methodology.

\section{RESULTS AND DISCUSSION}

\section{Studies with $\mathrm{Sm}$}

Streptomycin has no effect on chlorophyll formation during the first I 2 to $\mathrm{I} 4 \mathrm{~h}$ of lightinduced chloroplast development in dark-grown non-dividing Euglena gracilis var. bacillaris (Bovarnick et al. 1974). After this time, however, further chlorophyll accumulation was inhibited almost completely.

\section{Cytochrome 552}

Cytochrome 552, a component of the photosynthetic electron transport chain in Euglena chloroplasts (Katoh \& San Pietro, 1967) increases during light-induced chloroplast development (Perini et al. 1964). Since the assay for this cytochrome is relatively insensitive, especially in the dark-grown organisms where comparable amounts of a closely absorbing 
Table I. Kinetics of appearance of cytochrome 552 during light-induced chloroplast development in resting Euglena in the presence and absence of streptomycin

\begin{tabular}{|c|c|c|}
\hline \multirow[b]{2}{*}{ Time in light $(\mathrm{h})$} & \multicolumn{2}{|c|}{$10^{11} \times$ cytochrome $52^{*}(\mu \mathrm{mol} /$ organism $)$} \\
\hline & $-\mathrm{Sm}$ & $+\mathrm{Sm}$ \\
\hline 6 & 0.01 & - \\
\hline 12 & $0.16 \pm 0.19$ & $0.14 \pm 0.13$ \\
\hline $24-36$ & $0.61 \pm 0.28$ & $0.23 \pm 0.19$ \\
\hline & $1 \cdot 90, \quad 1 \cdot 50$ & - \\
\hline $68-117$ & $2 \cdot 80 \pm 0.44$ & $0.39 \pm 0.23$ \\
\hline
\end{tabular}

* Here and in subsequent Tables, each value reported represents the mean of several experiments, \pm the $95 \%$ confidence interval of the mean.

Table 2. Kinetics of the appearance of ribulose diphosphate carboxylase activity during lightinduced chloroplast development in resting Euglena in the presence and absence of streptomycin

$\begin{array}{ccc}\text { Time in light (h) } & \begin{array}{c}\text { Ribulose diphosphate carboxylase } \\ (\mu \mathrm{mol} \mathrm{CO} \text { fixed/mg protein } / \mathrm{h})\end{array} \\ 0 & -\mathrm{Sm} & +\mathrm{Sm} \\ 6-9 & 0.16 \pm 0.04 & - \\ 12 & 0.19 \pm 0.04 & - \\ 12-24 & 0.23 \pm 0.14 & - \\ 16-24 & 0.39 \pm 0.14 & 0.23 \pm 0.08 \\ 24-50 & - & 0.14 \pm 0.04 \\ 48 & 1.63 & - \\ 55-115 & 4.14 \pm 0.45 & 0.14 \pm 0.01\end{array}$

$c$-type mitochondrial cytochrome (cytochrome 556) are present, one cannot say with assurance that it is absent from the dark-grown organisms or that it definitely increases during the first $\mathrm{I} 2 \mathrm{~h}$ of development, although this seems to be the trend in the present data and in previous studies (Table I; Perini et al. 1964). When plastid development was carried out in the presence of $\mathrm{Sm}$, comparable levels were found at $\mathrm{I} 2 \mathrm{~h}$ in the controls and the Smtreated organisms but the increase beyond $12 \mathrm{~h}$ was blocked (Table $\mathrm{I}$ ). Thus the behaviour of cytochrome 552 during development in the presence of $\mathrm{Sm}$ resembles that of chlorophyll.

\section{Ribulose diphosphate carboxylase (RUDPCase)}

RUDPCase was already present at substantial levels in the dark-grown organisms and did not increase during the first $12 \mathrm{~h}$ of development (Table 2). Thus, Sm had no effect during the first $12 \mathrm{~h}$, but beyond this point the formation of RUDPCase was almost completely inhibited. Again, the pattern of inhibition is like that of chlorophyll and cytochrome 522 formation.

We have recently demonstrated that dihydrostreptomycin binds specifically to $68 \mathrm{~S}$ Euglena chloroplast ribosomes (Schwartzbach et al. 1973). Since $\mathrm{Sm}$ is an inhibitor of translation on bacterial $70 \mathrm{~S}$ ribosomes (Modolell \& Davis, I968), it seems likely that $\mathrm{Sm}$ specifically inhibits translation on Euglena $68 \mathrm{~S}$ chloroplast ribosomes. The lack of effect on division or viability (Provasoli et al. I948; Bovarnick et al. 1974) would seem to exclude any inhibitory effect of $\mathrm{Sm}$ on the $87 \mathrm{~S}$ cytoplasmic ribosomes, or on the mitochondrial system (Avadhani \& Buetow, $1972 a, b$ ) since Euglena is an obligate aerobe. Since protein synthesis on mitochondrial ribosomes has been shown to be inhibited by $\mathrm{Sm}$ and $\mathrm{Cm}$ (Avadhani \& Buetow, $1972 a, b$ ), the mitochondria may be impermeable to these antibiotics. 
Table 3. Kinetics of appearance of NADP-linked triose phosphate dehydrogenase during light-induced chloroplast development in resting Euglena in the presence and absence of streptomycin and of cycloheximide

NADP-linked triose phosphate dehydrogenase ( $\mu \mathrm{mol}$ NADPH oxidized/mg protein/h)

Time in light (h)

0
12
24
$36-48$
$72-96$

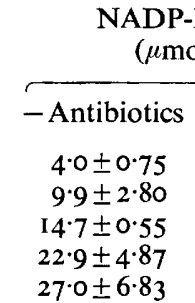

$\begin{array}{cc}+ \text { Streptomycin } & + \text { Cycloheximid } \\ 4 \cdot 0 \pm 0 \cdot 75 & 2 \cdot 7 \\ 9 \cdot 15 \pm \mathrm{I} \cdot 9 \mathrm{I} & 2 \cdot 6 \\ 12 \cdot 00,12 \cdot 6 & 1 \cdot 7 \\ 19 \cdot 9 & 2 \cdot 5,2 \cdot 0 \\ 16 \cdot 0 \pm 6 \cdot 25 & \mathrm{I} \cdot 3\end{array}$

Table 4. Specific activity of DPN-linked triose phosphate dehydrogenase during light-induced chloroplast development in resting Euglena in the presence and absence of streptomycin

$\begin{array}{ccc}\text { Time in light }(\mathrm{h}) & -\mathrm{Sm} & +\mathrm{Sm} \\ 0 & 43 \cdot 5 \pm \mathrm{I} 5 \cdot 0 & 43 \cdot 5 \pm \mathrm{I} \cdot \mathrm{O}^{\circ} \\ \mathrm{I} 2-24 & 33 \cdot 0 \pm 8 \cdot 0 & 34 \cdot 0 \pm \mathrm{I} \cdot 0^{\circ} \\ 3 \mathrm{I}-55 & 30 \cdot 3 \pm 4 \cdot 0 & 35 \cdot 0 \pm \mathrm{II} \cdot 0 \\ 60-96 & 26 \cdot 8 \pm 6 \cdot 0 & 32 \cdot 0 \pm 6 \cdot 0\end{array}$

\section{TPN-linked triose phosphate dehydrogenase (NADP-TP Dase)}

The NADP-TPDase showed quite a different pattern (Table 3). It developed within an apparent lag and its formation was relatively insensitive to $\mathrm{Sm}$. Although there was some difference between the controls and Sm-treated cells at $72 \mathrm{~h}$, the $95 \%$ confidence ranges of the means overlap and the variability makes it doubtful that even this difference is significant. Table 3 also shows that cycloheximide, an inhibitor of translation on $87 \mathrm{~S}$ ribosomes, completely inhibited the increase. Thus, this enzyme does not appear to be synthesized on the $68 \mathrm{~S}$ chloroplast ribosomes and is probably translated on the Sm-resistant cycloheximidesensitive ribosomes of the cytoplasm. This leaves open the question of whether mitochondrial ribosomes might participate. The electron micrographs of mitochondria in whole organisms show few or no ribosomes (Schiff, I970), but ribosomes isolated from the mitochondrial fraction are not sensitive to cycloheximide (Avadhani \& Buetow, 1972 $a, b$ ). If we assume that mitochondria are permeable to cycloheximide, then the cycloheximide sensitivity of the NADP-TPDase would argue against the mitochondrion being a site of synthesis for this enzyme.

The NAD-linked triose phosphate dehydrogenase (Table 4) from the cytoplasm of Euglena (probably the glycolytic enzyme) decreased slightly during plastid development, but $\mathrm{Sm}$ appeared to have little or no effect.

\section{Studies with chloramphenicol $(\mathrm{Cm})$}

Chloramphenicol is another inhibitor which is thought to block translation on bacterial $70 \mathrm{~S}$ ribosomes and which has no effect on the viability or growth of Euglena at the concentrations we employed (Provasoli et al. 1948; Smillie et al. 1963, 1967). This antibiotic showed essentially the same pattern of inhibition as Sm (Table 5). To ensure that these results were not due to some side effect of $\mathrm{Cm}$, following Ellis (1969) we used the same 
Table 5. Changes in various parameters during light-induced chloroplast development in resting Euglena in the presence and absence of chloramphenicol

\begin{tabular}{|c|c|c|c|}
\hline \multirow[b]{2}{*}{ Parameter } & \multirow[b]{2}{*}{ No light } & \multicolumn{2}{|c|}{ Light for $72 \mathrm{~h}$} \\
\hline & & $-\mathrm{Cm}$ & $+\mathrm{Cm}$ \\
\hline 1 (pg/organism) & 0 & $10.07 \pm 1.59$ & $4.95 \pm 0.83$ \\
\hline $\begin{array}{l}\text { esis (pmol } \mathrm{CO}_{2} \\
\mathrm{hism} / 10 \mathrm{~min} \text { ) }\end{array}$ & 0 & $0.265 \pm 0.058$ & $0.07 \pm 0.02$ \\
\hline$\left(\mu \mathrm{mol} \mathrm{CO}{ }_{2}\right.$ fixed $/ \mathrm{mg}$ & $0.053,0.046$ & $2 \cdot 11,9 \cdot 68,3 \cdot 32$ & $0.807, \mathrm{I} \cdot 43,0.59$ \\
\hline $\begin{array}{l}\text { Dase }(\mu \mathrm{mol} \text { NADPH } \\
\text { ig protein } / \mathrm{h})\end{array}$ & $6 \cdot 17,4 \cdot 26$ & $31 \cdot 40,40 \cdot 37,35 \cdot 75$ & I $8 \cdot 60,37 \cdot 34,28 \cdot 46$ \\
\hline
\end{tabular}

Table 6. Comparison of various parameters of light-grown resting $\mathrm{W}_{3} \mathrm{BUL}$ and of wild-type resting Euglena after $72 \mathrm{~h}$ of chloroplast development

Chlorophyll (pg/organism)

Photosynthesis (pmol $\mathrm{CO}_{2}$

fixed/organism/10 $\mathrm{min})$

RUDPCase $(\mu \mathrm{mol} \mathrm{CO}$ fixed $/ \mathrm{mg}$ protein $/ \mathrm{h})$

NADP-TPDase ( $\mu \mathrm{mol}$ NADPH

oxidized/mg protein $/ \mathrm{h}$ )

$\begin{array}{cc}\begin{array}{c}\mathbf{W}_{\mathbf{3}} \mathrm{BUL} \\ \text { Plastid largely absent } \\ \text { Not detectable }\end{array} & \begin{array}{c}\text { Wild type } \\ \text { Chloroplast } \\ \text { Present }\end{array} \\ 0 & 10.50 \pm 0.86 \\ 0.13 & 2.62 \pm 0.19 \\ 0 & 28 \\ 0 & 2.79 \pm 0.39 \\ 0 & 4.11 \pm 0.34 \\ 4.0 \mathrm{I} & 27.00 \pm 6.83 \\ 40.10 & 27.00 \pm 5.42\end{array}$

Structure

Plastid DNA

Chlorophyll (pg/organism)

Carotenoids (pg/organism)

$10^{2} \times$ photosynthesis

(pmol $\mathrm{CO}_{2}$ fixed/organism/h)

$10^{11} \times$ cytochrome 552

( $\mu \mathrm{mol} /$ organism)

RUDPCase $\left(\mu \mathrm{mol} \mathrm{CO}_{2}\right.$

fixed/mg protein/h)

NADP-TPDase ( $\mu$ mol TPNH oxidized $/ \mathrm{mg}$ protein $/ \mathrm{h}$ )

NAD-linked triose phosphate ( $\mu$ mol NADH oxidized/mg

protein/h)

\section{$\mathrm{w}_{3} \mathrm{BUL}$}

lastid largely absent

tetectable

0.13

$40 \cdot 10$
Wild type
Chloroplast
Present
$10.50 \pm 0.86$
$2.62 \pm 0.19$
28
$2.79 \pm 0.39$
$4.11 \pm 0.34$
$27.00 \pm 6.83$
$27.00 \pm 5.42$

40

concentrations of the L-threo isomer of $\mathrm{Cm}$, which does not inhibit protein synthesis but shows many of its side effects. This isomer had no effect on chloroplast development in Euglena (W. Li and J. A. Schiff, unpublished results).

\section{Investigation of mutant $\mathrm{W}_{3} \mathrm{BUL}$}

Mutant $w_{3} B U L$ is one of several Euglena strains in which plastid DNA is undetectable (Edelman et al. 1965). Chlorophyll, carotenoids, photosynthetic carbon dioxide fixation, cytochrome 552 and RUDPCase were all undetectable in this mutant even when grown in the light (Table 6). The NAD-linked triose phosphate dehydrogenase was present at normal levels. The NADP-TPDase, however, was present at precisely the same levels in the mutant as in the dark-grown wild-type organisms (compare Table 3). This suggests that NADPTPDase is not coded in the plastid DNA, which is absent; it is probably coded in the nuclear DNA. The fact that the levels found are the repressed levels of the dark-grown organisms indicates that this mutant lacks the machinery to induce the higher levels of this enzyme formed during chloroplast development. Possibly, the activity in the mutant represents a small non-specificity of the NAD-linked enzyme allowing it to use NADP, although studies in other organisms and in Euglena indicate that the NAD enzyme has an extremely high specificity for DPN and no activity with NADP (Pupillo, 1972). 
Table 7. Total protein during chloroplast development in resting Euglena in the presence and absence of streptomycin

\begin{tabular}{ccc} 
Time in light $(\mathrm{h})$ & \multicolumn{1}{c}{ Protein content (pg/cell) } \\
0 & 130 & $+\mathrm{Sm}$ \\
10 & $12 \mathrm{I}$ & 130 \\
36 & $\mathrm{I3I}$ & 137 \\
72 & II & 148 \\
& & 134
\end{tabular}

Table 8. Protein content of dark-grown non-dividing Euglena after $72 \mathrm{~h}$ incubation in darkness or in the light

The S.E. 95 was computed as follows. The standard deviation of the measurements (S.D.) was computed in the usual way. The standard error of the mean (S.E.M.) was computed from S.E.M. = S.D./ $\sqrt{ } n$ and was multiplied by $t_{95}$ for the appropriate number of degrees of freedom to yield S.E.95.

The variances of $A$ and $B$ were compared by means of the variance ratio ( $F$ test) where $F_{3}^{3}=\mathbf{I} \cdot 9$ $(P>10 \%$ ). Using the combined variance of $A$ and $B$ the significance of the difference from zero of the mean of the population $(A-B)$ was determined by means of the usual $t$ test where $t=2.63$ $(P>5 \%)$.

$\begin{array}{lccc}\begin{array}{c}\text { Culture } \\ \text { number }\end{array} & \begin{array}{c}\text { Light-exposed } \\ \text { half of } \\ \text { culture }(A)\end{array} & \begin{array}{c}\text { Dark-incubated } \\ \text { half of } \\ \text { culture }(B)\end{array} & \begin{array}{c}\text { Difference } \\ (A-B)\end{array} \\ \text { I } & \text { I77 } & 152 & -25 \\ \text { II } & 135 & 197 & +62 \\ \text { III } & \text { I50 } & 160 & +10 \\ \text { IV } & \text { I4I } & 136 & -5 \\ \bar{x} \pm \text { S.E. } 95^{*} & \text { I5I } \pm 30 & 16 I \pm 4 I & +42\end{array}$

* Mean of measurements $(\bar{x})$ plus or minus the standard error of the mean for $95 \%$ confidence level (S.E.95).

\section{Cell protein during development}

The total protein/organisms did not change significantly during light-induced chloroplast development in resting Euglena, and this was unaffected by Sm (Tables 7 and 8). This is consistent with previous findings that total RNA content does not change significantly during plastid development in resting organisms (Zeldin \& Schiff, 1968).

Since many new proteins are presumably made during plastid development, and since the overall protein content of the cells does not change, there must be considerable protein turnover during plastid development. This is not unexpected since these organisms are resting and starving; turnover under conditions of starvation is a widespread phenomenon in micro-organisms. The turnover mechanism must be carefully controlled by the algae since there is no change in cellular protein content even when plastid protein synthesis is blocked by $\mathrm{Sm}$.

\section{General conclusions}

The Euglena cell contains at least three different DNA genomes localized in the nucleus, mitochondrion and chloroplast respectively (Schiff, 1971; Edelman et al. 1965; Nass \& Ben-Shaul, 1972), and at least two and perhaps three sets of ribosomes (Rawson \& Stutz, I968; Scott \& Smillie, I969), the $68 \mathrm{~S}$ of the plastid, the $87 \mathrm{~S}$ of the cytoplasm and perhaps a mitochondrial species (Avadhani \& Buetow, 1972a,b). The mitochondrial DNA is small, with a molecular weight of only about $3 \times 10^{6}$ (Ray \& Hanawalt, 1964; Shori, Ben-Shaul \& 
Edelman, 1970); it therefore possesses a very limited amount of potential information, less than that required to build a mitochondrion, and it seems reasonable to think that mitochondrial DNA would not contribute significantly to the formation of proteins for the plastid. The nucleus and chloroplast contain relatively large amounts of DNA and are good candidates for the sources of information for plastid biosynthesis. Although cytochrome 552 and RUDPCase are absent from a mutant ( $\mathrm{W}_{3} \mathrm{BUL}$ ) in which plastid DNA is undetectable, this cannot be interpreted as unequivocal evidence that they are coded or controlled in the plastid DNA. Plastid ribosomal RNA hybridizes selectively with plastid DNA (Stutz \& Vandrey, 1971) indicating that the ribosomal RNA is coded in the plastid DNA. Since plastid DNA is undetectable in $\mathrm{W}_{3} \mathrm{BUL}$, it is probable that the ribosomes are deleted as well (Cohen \& Schiff, 1973) and along with them the ability to translate messages. It is possible that a message coming from elsewhere fails to be translated owing to the absence of plastid ribosomes in this mutant. Regulatory interactions as well are not ruled out. However, since $\mathrm{Cm}$ and $\mathrm{Sm}$ inhibit the formation of cytochrome $55^{2}$ and RUDPCase, these must be synthesized on plastid ribosomes.

The plastid NADP-TPDase, however, is formed even in the presence of $\mathrm{Sm}$ and $\mathrm{Cm}$ and its appearance is completely inhibited by cycloheximide, indicating that it is not synthesized on plastid ribosomes but on the $87 \mathrm{~S}$ ribosomes of the cytoplasm. Similar observations and conclusions have been reported for two other enzymes induced during chloroplast development: Euglena alkaline DNase (Egan \& Carell, 1972) and the chloroplast phenylalanyltRNA synthetase (Reger, Fairfield, Epler \& Barnett, 1970). We surmise, therefore, that enzymes such as NADP-TPDase, Euglena alkaline DNase and chloroplast phenylalanyltRNA synthetase are coded [in nuclear DNA. Thus these enzymes seem to be synthesized in the cytoplasm but later transported to the plastid, a situation reminiscent of the mitochondrial cytochrome $c$ of yeast where the structural gene has been shown to be nuclear (Mounolu, Jacob \& Slonimski, 1966; Huang, Briggs, Clark-Walker \& Linnane, 1966; Sherman et al. 1968). The possibility that the NADP-TPDase arises by a minor modification of the cytoplasmic NAD-linked triose phosphate dehydrogenase has been suggested for other organisms where coenzyme-induced modifications or other conformational changes are suggested for the conversion (Hudock \& Fuller, I965; Muller, 1970; Melandri, Pupillo \& Baccarini-Melandri, 1970; Baccarini \& Melandri, 1970). The synthesis of NADPTPDase, Euglena alkaline DNase, and chloroplast phenylalanyl-tRNA synthetase are repressed to the same extent in both wild-type dark-grown organisms and in $\mathrm{w}_{3} \mathrm{BUL}$. If control of these enzymes is at the level of a nuclear gene, normal conditions of derepression by light involve either a signal from the proplastid to the nucleus, or a separate nonchloroplast photoreceptor as previously suggested in connection with RNA synthesis (Schiff \& Zeldin, 1968; Schiff, 1971; Cohen \& Schiff, 1973). Once the light is turned on, the chloroplasts may exert control over the amount of enzyme available to enter the plastids.

This work was supported by grant GM 14595 from the National Institutes of Health. J.M.E. was a Public Health Service trainee. 


\section{REFERENCES}

Avadhani, N. G. \& Buetow, D. E. (1972a). Protein synthesis with isolated mitochondrial polysomes. Biochemical and Biophysical Research Communications 46, 773-778.

Avadhani, N. G. \& Buetow, D. E. (1972 $b$ ). Isolation of active polyribosomes from the cytoplasm, mitochondria and chloroplasts of Euglena gracilis. Biochemical Journal 128, 353-365.

BaCCARINI, A. \& MelandRI, B. A. (1970). Relationship between increased NADP-linked glyceraldehyde3-phosphate dehydrogenase activity and protein synthesis during the greening of etiolated pea seedlings. Physiologia plantarum 23, 444-45I.

Bovarnick, J. G., Chang, S. W., Schiff, J. A. \& Schwartzbach, S. D. (1974). Events surrounding the early development of Euglena chloroplasts: experiments with streptomycin in non-dividing cells. Journal of General Microbiology 83, 51-62.

Bovarnick, J. G., Freedman, Z. \& Schiff, J. A. ( 1970). Cellular origins of chloroplast enzymes in Euglena. Plant Physiology 46, S $2 \mathrm{I}$.

Cohen, D. \& Schiff, J. A. (1973). Photoregulation of formation and turnover of chloroplast rRNA (ChlrRNA) and cytoplasmic rRNA (CytrRNA) during chloroplast development in Euglena gracilis Klebs var. bacillaris Pringsheim. Biophysical Journal 13, I I Ia.

Edelman, M., SchifF, J. A. \& Epstein, H. T. (1965). Studies of chloroplast development in Euglena. XII. Two types of satellite DNA. Journal of Molecular Biology II, 769-774.

Egan, J. M., Jun. \& Carell, E. F. (1972). Studies on chloroplast development and replication in Euglena. III. A study of the site of synthesis of alkaline deoxyribonuclease induced during chloroplast development in Euglena gracilis. Plant Physiology 50, 39I-395.

Ellis, R. J. (1969). Stereospecificity of inhibition by chloramphenicol. Science, New York 158, 477-478.

Fuller, R. C. \& GibBs, M. (I959). Intracellular and phylogenetic distribution of ribulose I,5-diphosphate carboxylase and D-glyceraldehyde-3-phosphate dehydrogenase. Plant Physiology 34, 324-329.

Heber, U., Pon, N. G. \& Heber, M. (I963). Localization of carboxydismutase and triose phosphate dehydrogenases in chloroplasts. Plant Physiology 38, 355-360.

Huang, M., Briggs, D. R., Clark-Walker, G. C. \& Linnane, A. W. (1966). Chloramphenicol inhibition of the formation of particulate mitochondrial enzymes of Saccharomyces cerevisiae. Biochimica et biophysica acta II4, 434-436.

Hudock, G. A. \& FulleR, R. C. (1965). Control of triose phosphate dehydrogenase in photosynthesis. Plant Physiology 40, 1205-I2I I.

Katoh, S. \& San Pietro, A. (1967). The role of $c$-type cytochrome in the Hill reaction with Euglena chloroplasts. Archives of Biochemistry and Biophysics 118, 488-496.

Latzko, E. \& GibBs, M. (I968). Distribution and activity of enzymes of the reductive pentose phosphate cycle in spinach leaves and in chloroplasts isolated by different methods. Zeitschrift Pflanzenphysiologie 59, 184-194.

Lowry, O. H., Rosebrough, J. J., Farr, A. L. \& Randall, R. J. (1951). Protein measurements with the Folin phenol reagent. Journal of Biological Chemistry 193, 265-275.

Melandri, B. A., Pupillo, P. \& Baccarini-Melandri, A. (1970). D-Glyceraldehyde-3-phosphate dehydrogenase in photosynthetic cells. I. The reversible light-induced activation in vivo of NADPdependent enzyme and its relationship to NAD-dependent activities. Biochimica et biophysica acta 220, $178-189$.

Modolell, J. \& Davis, B. D. (1968). Rapid inhibition of polypeptide chain extension by streptomycin. Proceedings of the National Academy of Sciences of the United States of America 6r, 1279-1286.

Mounolu, J. C., JACOB, H. \& Slonimski, P. P. (1966). Molecular nature of the hereditary cytoplasmic factors controlling gene expression in mitochondria. In The Control of Nuclear Activity. Edited by

L. Goldstein. Englewood Cliffs, New Jersey: Prentice-Hall.

MULLER, B. (1970). On the mechanism of the light-induced activation of the NADP-dependent glyceraldehyde phosphate dehydrogenase. Biochimica et biophysica acta 205, 102-109.

Nass, M. K. \& Ben-Shaul, Y. (1972). A novel closed circular duplex DNA in bleached mutants and green strains of Euglena gracilis. Biochimica et biophysica acta 272, 130-136.

Nishimura, M. (1959). A new hematin compound isolated from Euglena gracilis. Journal of Biochemistry 46, 2I9-223.

Perini, F., Schif, J. A. \& Kamen, M. D. (1964). Iron-containing proteins in Euglena. II. Functional localization. Biochimica et biophysica acta 88, 9I-98. 
Provasoli, L., Hutner, S. H. \& Schatz, A. (1948). Streptomycin-induced chlorophyll-less races of Euglena. Proceedings of the Society for Experimental Biology and Medicine 69, 279-282.

Pupillo, P. (1972). The specificity of glyceraldehyde-3-phosphate dehydrogenase in green plants, Euglena and Ochromonas. Phytochemistry II, I53-I6r.

RAwson, J. R. \& STUtz, E. (1968). Characterization of Euglena cytoplasmic ribosomes and ribosomal RNA by zone velocity sedimentation in sucrose gradients. Journal of Molecular Biology 33, 309-3I4.

Ray, D. S. \& Hanawalt, P. C. (1964). Properties of the satellite DNA associated with the chloroplasts of Euglena gracilis. Journal of Molecular Biology 9, 8I 2-824.

Reger, B. J., Fairfield, S. A., Epler, J. L. \& Barnett, W. E. (i970). Identification and origin of some chloroplast aminoacyl-tRNA synthetases and tRNAs. Proceedings of the National Academy of Sciences of the United States of America 67, 1207-1213.

SCHIFF, J. A. (1970). Developmental interactions among cellular compartments in Euglena. In Autonomy and Biogenesis of Mitochondria and Chloroplasts, pp. 98-I 18. Amsterdam: North Holland Publishing.

SCHIFF, J. A. ( I97I). The informational and nutritional requirements of cellular organelles. Stadler Symposia $3,89-113$.

Schiff, J. A. \& Zeldin, M. H. (1968). The developmental aspect of chloroplast continuity in Euglena. Journal of Cell Physiology 72, S 103-1 28.

SChiff, J. A., Zeldin, M. H. \& Rubman, J. (1967). Chlorophyll formation and photosynthetic competence in Euglena during light-induced chloroplast development in the presence of 3 (3,4-dichlorophenyl) I,I-dimethyl urea (DCMU). Plant Physiology 42, 1716-1725.

Schwartzbach, S. D., Freyssinet, G. \& SchifF, J. A. (1973). Binding of dihydrostreptomycin to Euglena chloroplast ribosomes prepared by an improved procedure. Plant Physiology 5I, S 27.

Scott, M. S. \& Smillie, R. M. (1969). Ribosomal RNA in chloroplasts of Euglena gracilis. Currents in Modern Biology 2, 339-342.

Sherman, F., Stewart, J. W., Parker, J. H., Inhaber, E., Shipman, N., Putterman, J., Gardinsky, R. \& Margoliash, E. (1968). The mutational alteration of the primary structure of yeast iso-I-cytochrome $c$. Journal of Biological Chemistry 243, 5446-5456.

Shori, L., Ben-Shaul, Y. \& Edelman, M. (1970). The size of mitochondrial DNA in Euglena gracilis. Israel Journal of Chemistry 8, i $17 \mathrm{P}$.

Smillie, R. M. (1968). Enzymology of Euglena. In The Biology of Euglena, vol. 2. Edited by D. Buetow. New York: Academic Press.

Smillie, R. M., Evans, W. R. \& Lyman, H. (1963). Metabolic events during the formation of a photosynthetic from a nonphotosynthetic cell. Brookhaven Symposia 16, 89-108.

Smillie, R. M., Graham, D., Dwyer, M. R., Grieve, A. \& Tobin, N. F. (1967). Evidence for the synthesis in vivo of proteins of the Calvin cycle and of the photosynthetic electron-transfer pathway on chloroplast ribosomes. Biochemical and Biophysical Research Communications 28, 604-610.

Stutz, E. \& VANDREY, J. P. (I97I). Ribosomal DNA satellite of Euglena gracilis chloroplast DNA. FEBS Letters $\mathbf{1 7}, 277-280$.

Wolken, J. J. \& Gross, J. A. (1963). Development and characteristics of the Euglena c-type cytochrome. Journal of Protozoology Io, I89-195.

Zeldin, M. H. \& SCHIFF, J. A. (I968). A comparison of light-dependent RNA metabolism in wild-type Euglena with that of mutants impaired for chloroplast development. Planta 8I, I-I5 